\title{
PENGARUH MODEL PEMBELAJARAN STUDENT TEAMS ACHIEVEMENT DIVISION (STAD) TERHADAP KEMAMPUAN MENULIS TEKS ULASAN CERPEN SISWA KELAS VIII SMP SULTAN ISKANDAR MUDA MEDAN TAHUN PELAJARAN 2018/2019
}

\author{
Juwita Theresia Bangun ${ }^{1}$, Annisa ${ }^{2}$, Ibrahim Daulay ${ }^{3}$ \\ Universitas Prima Indonesia ${ }^{1}$, Universitas Prima Indonesia ${ }^{2}$, Universitas Prima Indonesia ${ }^{3}$ \\ Pos-el: juwitatheresia@yahoo.com¹, rindi.nisa48@gmail.com² daulay_ibrahim@yahoo.co.id ${ }^{3}$,
}

\begin{abstract}
ABSTRAK
Penelitian ini bertujuan untuk mengetahui pengaruh model pembelajaran STAD terhadap kemampuan menulis teks ulasan cerpen siswa kelas VIII SMP Sultan Iskandar Muda Medan Tahun Pelajaran 2018/2019. Penelitian ini merupakan penelitian kuantitatif menggunakan metode eksperimen degan desain true design. Populasi dalam penelitian ini adalah siswa kelas VIII Sultan Iskandar Muda Medan yang berjumlah 168 siswa. Penentuan sampel dengan teknik random sampling. Berdasarkan teknik tersebut diperoleh kelas VIII-A sebagai kelas eksperimen terdiri dari 41 siswa dan kelas VIII-B sebagai kelas kontrol terdiri dari 41 siswa. Teknik pengumpulan data dengan menggunakan tes, yaitu post-test. Proses pengumpulan data dengan cara menugaskan siswa menulis teks ulasan cerpen. Sebelum dilakukan analisis data, terlebih dahulu dilakukan uji normalitas dan uji homogenitas yang menunjukkan bahwa skor post-test berdistribusi normal dan homogen. Teknik analisis data adalah uji- t. Hasil penelitian menunjukkan adanya perbedaan kemampuan menulis teks ulasan cerpen siswa kelas VIII Smp Sultan Iskandar Muda Medan dengan menggunakan model STAD dan tanpa menggunakan model STAD. Perbedaan tersebut ditunjukkan oleh hasil uji- $t$ yaitu thitung $=18,90$, ttabel $=1,99$, sehingga kriteria pengujian hipotesis penelitian ini adalah thitung $>$ ttabel, maka hipotesis nilai H0 ditolak dan hipotesis alternative (Ha) diterima. Hal ini membuktikan bahwa terdapat pengaruh positif model pembelajaran STAD dari pada tanpa model pembelajaran STAD terhadap kemampuan menulis teks ulasan cerpen siswa kelas VIII SMP Sultan Iskandar Muda Medan Tahun Pelajaran 2018/2019.
\end{abstract}

Kata Kunci: Student Teams Achievement Division (STAD), Menulis, Teks Ulasan Cerpen.

\section{ABSTRACT}

This study aims to determine the effect of Student Teams Achivement Division (STAD) learning model on the ability to writing short story review text by class VIII SMP Sultan Iskandar Muda Medan in the academic year of 2018/2019. This is quantitative research using true experimental design. The population of this study were 168 students of class VIII SMP Sultan Iskandar Muda Medan. Samples were drawn by random sampling technique. Based on the technique, VIII-A was determined as the experimental class, and class VIII-B as the control class. The experimental class consists of 41 students and the control class consisted of 41 students. The data collection was performed used the test, the post-test. The process of collecting data by assigning students to write short story review text based on short stories given by researchers, while in the control class write and review short stories with unforgettable themes. Prior to the data analysis, normality, homogenity test we done which showed thad post-test scores were normally distributed dan homogeneus. Data analysis technique used is the t-test. the result showed that there is a difference in the ability to writing short story review text of class VIII SMP Sultan Iskandar Muda Medan using Student Teams 
Achievement Division (STAD) learning model. The different was shown by the results of the ttest is $t=18,90$, table $=1,99$, -table $=-1,99$ so, the research hypothesis testing criteria are: ttable $<$ tcount $>$ ttable, then the value hyphothesis $\mathrm{HO}$ is rejected and the alternative hypothesis (Ha) is accepted. This proves that there is a positive effect of Student Teams Achievement Division (STAD) learning model on the ability to writing short story review text by class VIII SMP Sultan Iskandar Muda Medan in the academic year of 2018/2019.

\section{Keywords: Student Teams Achievement Division (STAD), Writing, Short Story Review Text.}

\section{PENDAHULUAN}

Pada kurikulum 2013, teks ulasan cerita pendek (cerpen) menjadi salah satu materi yang dipelajari siswa dalam pembelajaran bahasa Indonesia. Teks ulasan merupan teks yang menarik untuk diteliti sebab teks ini mengajarkan siswa untuk mengulas berbagai jenis karya sastra seperti cerpen, novel, puisi, dan sebagainya. Teks ulasan juga dapat menambah pengetahuan dan wawasan siswa mengenai berbagai karya sastra yang belum diketahui.

Kemampuan siswa dalam menulis teks ulasan cerpen tergolong rendah. Hal ini dapat dibuktikan dari hasil nilai siswa dalam menulis pantun berkisar 40 sampai 70 atau di bawah KKM yang semestinya 75 yang diketahui dari hasil wawancara dengan guru bidang studi bahasa Indonesia. Minimnya penggunaan model pembelajaran yang digunakan oleh guru perlu diatasi sedikit demi sedikit, sehingga dapat membantu siswa dalam hal teori dan praktiknya, serta dapat memotivasi siswa dalam membuat sebuah karya tulis. Menulis cerpen juga tidak harus menggunakan bahasa ataupun kalimat yang terlalu rumit, melainkan bisa menggunakan bahasa yang sederhana dan juga kalimat yang mudah dipahami.

Proses belajar mengajar dapat dilakukan apabila siswa memfokuskan diri dalam mendengarkan informasi yang diberikan oleh guru dan juga siswa ikut berpartisipasi dalam kegiatan pembelajaran. Untuk dapat membantu siswa dalam membuat sebuah cerpen, perlu adanya sarana pendukung secara mandiri ataupun sebuah motivasi. Dengan adanya sarana pendukung siswa dapat berlatih meningkatkan kemampuan menulis sebuah cerpen di dalam kelas maupun diluar kelas.

Oleh karena itu, model pembelajaran STAD adalah model yang tepat dalam menulis teks ulasan cerpen, maka peneliti akan melakukan penelitian dengan judul "Pengaruh Model Pembelajaran Student Teams Achievement Division (STAD) terhadap kemampuan menulis teks ulasan cerpen siswa kelas VIII SMP Sultan Iskandar Muda Medan Tahun Pelajaran 2018/2019 ". Penelitian ini bertujuan untuk mengetahui pengaruh Model Pembelajaran STAD terhadap kemampuan menulis teks ulasan cerpen siswa kelas VIII SMP Sultan Iskandar Muda Medan Tahun Pelajaran 2018/2019".

Menurut Soekamto (dalam

Shoimin, 2016:23) "Model pembelajaran adalah kerangka konseptual yang melukiskan prosedur yang sistematis dalam mengorganisasikan pengalaman belajar untuk mencapai tujuan belajar tertentu, dan berfungsi sebagai pedoman bagi para perancang pembelajaran dan para 
pengajar dalam merencanakan aktivitas belajar mengajar."

"Fungsi model pembelajaran adalah sebagai pedoman bagi pengajar dan para guru dalam melaksanakan pembelajaran. Hal ini menunjukkan bahwa setiap model yang akan digunakan dalam pembelajaran menentukan perangkat yang dipakai dalam pembelajaran tersebut." (Shoimin, 2016:24). sehingga disimpulkan bahwa yang dimaksud model pembelajaran adalah suatu bahan atau alat dalam kegiatan pembelajaran yang harus dikerjakan oleh guru dengan tujuan agar siswa dapat mencapai hasil yang efektif sesuai dengan yang diinginkan.

Menurut Slavin (2005:143) menyatakan " model STAD ini merupakan salah satau model pembelajaran kooperatif yang paling sederhana dan dianjurkan digunakan guru sebagai pemulaan dalam menggunakan pendekatan kooperatif.

Model pembelajaran Student Teams Achievement Division (STAD) sangat mendukung kegiatan proses belajar mengajar yang tidak hanya berpusat pada guru, karena model pembelajaran Student Teams Achievement Division (STAD) sangat membantu siswa dapat menjadi lebih aktif dalam kegiatan belajar mengajar. Siswa dapat dengan leluasa memahami serta meningkatkan kerjasama antar kelompok selain itu, siswa juga dinilai kerja secara individualnya.

Menulis dapat membuat siswa menuangkan isi pikiran dan perasaan yang mereka rasakan ke dalam bentuk tulisan-tulisan, sehingga dapat menjadi pesan-pesan yang menarik perhatian para pembacanya.

$$
\text { Menurut Tarigan }
$$

Mengemukakan bahwa "Menulis ialah menurunkan atau melukiskan lambanglambang grafis yang menggambarkan suatu bahasa yang dipahami oleh seseorang, sehingga orang-orang lain dapat membaca lambang-lambang grafik tersebut kalau mereka memahami bahasa dan gambaran grafik itu"

Menurut kosasih (2016:70) "Teks ulasan (review) adalah teks yang berisi penilaian tentang kelemahan dan kelebihan suatu karya. Karya yang dimaksud dapat berupa cerpen, puisi, novel, film, bahkan karya seni daerah." selain itu, "Teks ulasan pada dasarnya sama dengan resensi yang intinya mengulas sebuah karya, baik berupa buku, fil, maupun teater, yang di dalamnya menilai atau memberikan tanggapan sebuah karya tersebut." (Rahmawati, 2015:11)

Menurut Jassin (dalam Nurgiyantoro 2015:12) mengatakan bahwa "cerpen adalah sebuah cerita yang selesai dibaca dalam sekali duduk, kira-kira berkisar antara setengah sampai dua jam, suatu hal yang kiranya tidak mungkin dilakukan untuk sebuah novel.

\section{METODE PENELITIAN}

Jenis penelitian ini merupakan eksperimen. Penelitian ini menggunakan pendekatan kuantitatif. Sugiyono (2013 : 7) mengatakatan pendekatan penelitian kuantitatif ialah metode penelitian yang berlandasan pada filsafat posivisme, digunakan untuk meneliti pada populasi atau sampel tertentu, pengumpulan data menggunakan instrument penelitian, analisis data bersifat kuantitatif/statistic, dengan tujuan untuk menguji hipotesis yang telah ditetapkan. Penelitian menggunakan pendekatan kuantitatif 
karena semua data yang berkumpul disusun dalam bentuk angka-angka yang selanjutnya dianalisis untuk mendapatkan suatu data.

Menurut Arikunto (2010:12)" desain atau rancangan penelitian dapat dikatakan alur pengumpulan data eksperimen pembelajaran yang dilaksanakan di dalam kelas berdasarkan jenis penelitiannya." Oleh sebab itu, eksperimen penelitian ini menggunakan desain two group postest design only. Desain ini memberikan perlakuan setelah dilakukan penentuan kelompok kontrol dan kelompok eksperimen. Selanjutnya, dilakukan pengukuran terhadap variabel terikat pada kedua kelompok tersebut.

\section{HASIL DAN PEMBAHASAN}

a. Kemampuan Menulis Teks Ulasan Cerpen Siswa Kelas Kontrol

Kemampuan menulis teks ulasan cerpen siswa kelas VIII SMP Sultan Iskandar Muda Medan tanpa menggunakan model pembelajaran STAD adalah sebagai berikut: tidak ada siswa dengan kategori sangat baik dengan rentang nilai 85-100, sebanyak 11 siswa 26,8\% dengan kategori baik dan rentang nilai 70-84, sebanyak 11 siswa 26,8\%, dengan kategori cukup dan rentang nilai 55-69, sebanyak 19 siswa 46,3\%, dengan kategori kurang dan rentang nilai 40-54, dan tidak ada siswa yang memiliki nilai sangat kurang dengan rentang nilai 0-39.

\section{b. Kemampuan Menulis Teks Ulasan Cerpen Siswa Kelas Eksperimen}

Kemampuan menulis teks ulasan cerpen siswa kelas VIII SMP Sultan Iskandar Muda Medan dengan menggunakan model pembelajaran STAD adalah sebagai berikut: sebanyak 10 siswa $24,4 \%$ dengan kategori sangat baik dan rentang nilai 85-100, sebanyak 17 siswa $41,4 \%$ dengan kategori baik dan rentang nilai $70-84$, sebanyak 14 siswa $34,1 \%$, dengan kategori cukup dan rentang nilai
55-69, dan tidak ada siswa yang memiliki nilai kurang dan sangat kurang dengan rentang nilai 40-54 dan 0-39.

Pembahasan pada penelitian ini didasarkan pada data pemerolehan nilai kelas kontrol dan kelas eksperimen. Data tersebut dari hasil posttest yang dijadikan bahan bagi peneliti untuk mendeskripsikan sekaligus menjawab tiga poin rumusan masalah.

Pertama, hasil posttest menunjukkan kemampuan menulis teks ulasan cerpen tanpa menggunakan model pembelajaran STAD pada kelas kontrol berada dalam kategori kurang atau belum memuaskan. Pada kelas kontrol diketahui nilai minimum yaitu 40 dan perolehan nilai maksimumnya yaitu 81 dengan nilai rata-rata 59,9.

Kedua, hasil

posttest

menunjukkan kemampuan menulis teks ulasan cerpen dengan menggunakan model pembelajaran STAD pada kelas eksperimen berada dalam kategori baik atau memuaskan. Pada kelas ekperimen diketahui nilai minimum yaitu 55 dan perolehan nilai maksimumnya yaitu 96 dengan nilai rata-rata 74,47.

Ketiga, keefektifan penggunaan model pembelajaran STAD dapat dilihat dari uji hipotesis dan yang peneliti lakukan terlebih dahulu adalah uji normalitas dan uji homogenitas pada kedua kelas. Hasil uji normalitas pada kelas kontrol yang diperoleh yaitu Lhitung $0,1165<$ Ltabel 0,1384 dan pada kelas eksperimen diperoleh Lhitung $0,1264<$ Ltabel 0,1384 atau dengan kata lain kedua kelas berada dalam kategori normal. Sedangkan dengan hasil uji homogenitas pada kelas kontrol dan kelas eksperimen dengan taraf signifikan $\alpha=0,05$ dan $\mathrm{dk}$ pembilang $=41$, dk penyebut $=41$ atau $($ F0,05(41,41) yaitu Fhitung < Ftabel $(1,10<1,69)$ dengan kata lain kedua kelas berada dalam kategori yang Homogen.

Kelas kontrol dan kelas eksperimen berada dalam kategori norlmal dan homogen, maka uji 
hipotesis dapat dilakukan. Hasil uji hipotesis menunjukkan nilai thitung > ttabel $(18,90>1,99)$ dengan kata lain Ha diterima atau penggunaan model pembelajaran STAD terbukti efektif diterapkan dalam pembelajaran menulis teks ulasan cerpen siswa kelas VIII SMP Sultan Iskandar Muda Medan.

\section{SIMPULAN}

Setelah dianalisis dan diolah data penelitian dan pembahasan, dapat disimpulkan tiga hal berikut ini: Pertama, kemampuan menulis teks ulasan cerpen pada siswa kelas VIII SMP Sultan Iskandar Muda Medan Tahun Pelajaran 2018/2019 tanpa menggunakan model pembelajaran STAD di kategorikan kurang. Hal ini dibuktikan dari nilai rata-rata kelas 59,91, dengan nilai maksimum 81 dan nilai minimum 40. Kedua, kemampuan menulis teks ulasan cerpen pada siswa kelas VIII SMP Sultan Iskandar Muda Medan Tahun Pelajaran 2018/2019 dengan menggunakan model pembelajaran STAD dikategorikan baik. Hal ini dibuktikan dengan nilai rata-rata 74,47, dengan nilai maksimum 96 dan nilai minimum 55. Ketiga, menulis teks ulasan cerpen dengan menggunakan model pembelajaran STAD sangat berpengaruh dalam meningkatkan kemampuan menulis teks ulasan cerpen. Hal ini dapat dilihat pada uji-t diketahui thitung > ttabel $(18,90>1,99)$ sehingga dalam penelitian ini $\mathrm{H} 0$ ditolak dan $\mathrm{Ha}$ diterima. Jadi dapat disimpulkan bahwa kemampuan menulis teks ulasan cerpen yang diajarkan dengan menggunakan model pembelajaran STAD berpengaruh lebih baik dibandingkan kemampuan menulis teks ulasan cerpen yang diajarkan dengan metode konvensional.

\section{DAFTAR PUSTAKA}

Kosasih, Engkos. 2016. Mandiri Bahasa Indonesia Untuk SMP/MTs Kelas VIII. Jakarta : Erlangga.
Kosasih, Engkos. 2018. Jenis-jenis Teks. Jakarta : Yrama Widya Shoimin,

Aris. 2016. 68 Model Pembelajaran Inovatif dalam Kurikulum 2013.

Nurgiyantoro, Burhan. 2015. Teori Pengkajian Fiksi. Yogyakarta : Gadjah Mada University Press.

Shoimin, Aris. 2016. 68 Model Pembelajaran Inovatif dalam Kurikulum 2013. Yogyakarta : AR-RUZZ MEDIA

Tarigan, Hendry Guntur. 2013. Keterampilan Menulis Sebagai Suatu Keterampilan Berbahasa. Bandung : Angkasa. 